\title{
Generic mapping of human activity-based exposure scenarios to petroleum hydrocarbon contaminants in an oil producing area of the Niger Delta region of Nigeria
}

\author{
W. J. Shittu, C. P. Nathanail \& R. J. Abrahart \\ School of Geography, University of Nottingham, UK
}

\begin{abstract}
Oil spills worldwide may occur during production and transportation by accident, equipment failure and error. However, the common cause in the Niger Delta region of Nigeria has been attributed to pipeline sabotage and vandalism. Over the past 50 years a total of 6,817 oil spill incidents have been recorded resulting in the discharge of more than 9 million barrels of crude oil into the environment of which over 70 per cent remains unrecovered. The negative impact of such oil spills on human health and the environment can be severe. Most of the oil spills in the region occur from pipeline discharge in or near rural communities where people survive mainly on naturally available resources, engaging daily in traditional activities like hunting, fishing, farming and gathering even at the risk of exposure to oil contaminated media.

This paper identify traditional rural activities in the region and map areas vulnerable to risk of exposure to petroleum hydrocarbon contaminants, base on a relative risk ranking model for traditional activities undertaken by the people. It indicates traditional activity with the highest risk according to age/gender following an average daily exposure scenario. To achieve this, oil spill site datasets from 1985 - 2008; spatial location of 354 rural communities; several kilometres of pipeline network digitised from SPOT satellite imaging was inputted into a GIS to map community proximity to oil pipeline routes and historic spill sites. Map overlay, buffering and Boolean operations were performed to determine community vulnerability to oil spill releases using proximity to pipelines and rivers, and land use type. The map will be beneficial
\end{abstract}


to oil companies, communities and government agencies in assessing the size of sites becoming polluted for remediation/management/compensations. Keywords: risk, contaminants, exposure, pathway, oil spill, pollution.

\section{Introduction}

The Niger Delta covers an area of about $70,000 \mathrm{~km}^{2}$. It contains more 800 oil producing communities, 1000 oil producing wells, in addition to flow stations, gas plants and about $4,315 \mathrm{~km}$ multi-product pipelines which criss-cross the delta [2]. In 1956 when the first oil-well was drilled by Shell in Oloibiri Bayelsa state, large quantities of crude was spewed into the environment and the people celebrated with a football match against the Shell staffs [3]; little did they know that oil spill will one day become a major environmental problem to confront them. Over the past 50 years more than 6,817 oil spill incidents have been recorded resulting in the discharge of about 9million barrels of crude with more than 70 per cent unrecovered [4]. This figure is nearly twice the quantity spilled in the Gulf of Mexico from BP's Macondo well in 2010. Amnesty International [5] pointed out that many polluted sites in the region have not been cleaned-up; as a result, the quality of the local water, food and livelihood has been compromised.

The majority of the oil spills in this region occur from pipeline discharge caused by equipment failure, operational error, sabotage and or vandalism. However, [1] claimed that oil theft and sabotage accounted for $98 \%$ of oil spill incidents in 2009, leading to the discharge of at least 14,000 metric tonnes or about 100,000 barrels of crude oil into the environment. This claim was collaborated by [6] indicating a total of 1,453 pipeline incidents attributed to vandalism in the same year.

Several International Oil Companies (IOCs) like Shell, Mobil, Chevron, Texaco, Total E\&P, Pan-Ocean and NAOC/Phillips operate joint venture agreements with the Nigerian Government through the Nigerian National Petroleum Corporation to produce about 2.2million barrel of crude per day [6] from onshore and offshore fields. The majority of onshore oil production takes place in the Niger Delta region comprise Abia, Akwalbom, Bayelsa, Cross River, Delta, Edo, Imo, Ondo and Rivers States (see Figure 1: insert). Of the $70,000 \mathrm{~km}^{2}$ total land mass of the region, about $31,000 \mathrm{~km}^{2}$ accommodates oil production facilities. The entire Niger Delta is inhabited by several traditional historic communities with a total population of 42.6 million [7].

The implications of oil production in this area are the taking over of common traditional land use space and high rate of pollution from incessant oil spills. In this paper risk related areas to actual and potential petroleum pollution are mapped using GIS to identify source of oil spill, type of land use activities, communities within and around historic oil spill sites. The basic aim of this paper is to identify traditional rural activities synonymous with the region and map areas vulnerable to risk of exposure to petroleum hydrocarbon contaminants using a traditional activity-based relative risk ranking model. 


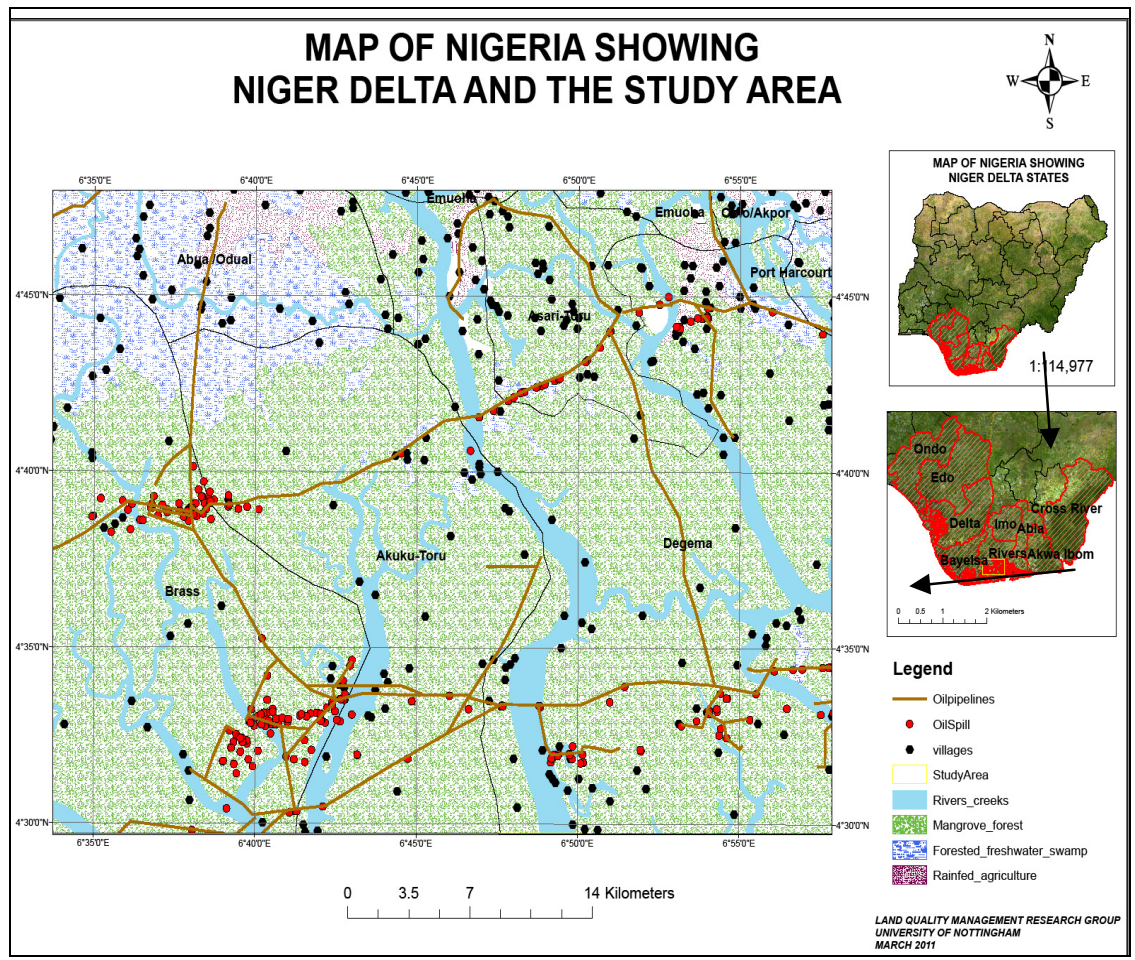

Figure 1: $\quad$ Study area in rivers state of Nigeria.

\subsection{Study area}

The study area consists of 354 communities in nine Local Government Areas in Rivers State and one in Bayelsa state covering approximately $1,939.8 \mathrm{Km}^{2}$ with a population of about 1.36million (NPC 2002 projection) (see Figure 1). The area is dissected by several river tributaries and creeks flowing towards the Atlantic Ocean to the south. The vegetation is a typical deltaic environment, made up of mangrove forests and fresh water swamps, with poorly to moderately drained soils consisting of sand, loamy sand, clay and sometimes gravels subsoil. The average annual rainfall is $3000 \mathrm{~mm}$ with $90 \%$ occurring between March and November with peak in July through September; as a result the area becomes inundated during the rainy seasons. The mean Temperature is $34^{\circ} \mathrm{C}$ during the hottest period around February and March while the coolest period is in August with a mean Temperature of $28^{\circ} \mathrm{C}$ [8]. Most of the communities in the area are fishing and farming hamlets located along river routes. Some $44.9 \%$ of the communities are located within $1.5 \mathrm{~km}$ of a river. The people are mostly associated with subsistent lifestyles like small scale farming, fishing, and animal herding and hunting. The study area is transverse by $314.3 \mathrm{~km}$ of pipeline network used for gathering and transporting crude from oil wells belonging to one or more oil companies. From the data collected, a total of 443 oil spill 
incidents have been recorded between 1985 and 2008, thus 129,578 barrels of crude oil has been discharged in the area with the greatest amount of pollution occurring in the period 2003-07.

\section{Traditional activities}

The communities are agrarian in nature depending on naturally occurring resources by engaging in activities like fishing, hunting, farming (crop cultivation), and animal herding at subsistence level. Other activities include fuel wood gathering for energy, water collection from local streams, lakes or ponds for domestic use. In carrying out these activities, the people travel long distance and spend a lot of time in the process, perhaps due to distance or because things are done manually $[10 ; 11]$.

\subsection{Land use activities}

Farming is a form of agricultural land use involving crop production. Kassali et al. [10] observed that farmers often walk approximately $6 \mathrm{~km}$ a day to their farms, perhaps due to population pressure, land tenure system or availability of fertile soils close to the settlements [12]. Fishing is a major activity supplying more than $80 \%$ of animal protein $[13,14]$, as a result, most communities are classified as fishing hamlets established to take advantage of fishing opportunities presented by the riverine ecosystem [15]. Animal herding is another practice in which families keep and rear sizable numbers of domesticated animals such as cattle, goat, pig and sheep [17]. The animals are usually taken out for grazing at locations where green pasture is available and to prevent animals from straying into farms or cultivated fields. Hunting activity deals with killing or capturing of wild animals for consumption as bush meat. While some hunt for subsistence purposes (i.e. for family consumption) others do it as a full time occupation where the objective is to satisfy market demand for bush meat [18]. Hunting is unrestricted in most forests in the region [19]. Fuelwood gathering is an activity synonymous with most rural communities; it serves as the cheapest source of energy for low income families who cannot afford alternatives e.g. kerosene stove, gas cooker or electric cooker [20]. Fuel wood remains the dominant energy source utilised in over $50 \%$ of rural households for cooking, heating and food processing [21]. Women and children traditionally collect fuel wood for household usage , according to Ikurekong et al, [21] women walk more than $4 \mathrm{~km}$ a day in search of fuel wood, sometimes because of access restrictions imposed on communal and family trees which compel them to gather from unrestricted marginal fields far away. Water collection is common activity requiring fetching water from natural sources for household needs. Women and children perform this role by undertaking multiple round trips over long distance carrying containers of water filled from different sources every day [23]. Nkwocha [23] claim that people travel a mean distance of approximately $5 \mathrm{~km}$ to fetch water, thus spending averagely between $2-5 \mathrm{hrs}$ daily. 


\subsection{Land use potential exposure scenarios and pathways}

In most African societies especially in the rural setting, day to day activities are designated among members according to culture and tradition. Over the years tradition has been used as a basis for assigning certain activities to specific genders or age groups. This way it is easy to identify the particular group or gender assigned to a specific activity and the type of land use associated with it. Such activities can be matched against western methods of contaminated land assessment where human health risk is assessed based on type of land use [25]. Land use activities help to understand how people behave; for instance frequency and duration of visits to a site, how and when the activity is performed. Thus the possibility of direct/indirect contact with contaminants can be determined especially where activity is performed on or near a contaminated source.

\subsection{Exposure pathways}

Human exposure to contaminants can occur through inhalation of dust and vapour, ingestion of soil or food grown on contaminated soil and dermal contact with contaminated media while performing an activity [26, 27]. The process of exposure begins with the introduction of a contaminant (agent) into the environment, where it is either transformed or transported through environmental media air, water, soil and dust and taken up through inhalation, ingestion and or dermal contact [26].

\subsubsection{Inhalation}

involves human respiration associated with air intake during breathing processes measured in cubic meters per hour $\left(\mathrm{m}^{3} / \mathrm{h}\right)$. The amount of airborne contaminant inhaled (measured in micrograms per cubic meter $\left(\mu \mathrm{g} / \mathrm{m}^{3}\right)$ is depended on the concentration of the contaminant, time spent at a specific location, the body weight of the receptor and the intensity of activity [28].

\subsubsection{Ingestion}

is a means of introducing substances into the body system through the mouth and can be categorised into dietary and non-dietary exposures. Dietary exposure is the intake of contaminated substances in food, drinking water and beverages. Non-dietary on the other hand is the consumption of food items contaminated by substances through contact with polluted hands or surfaces, as well as ingestion of residues while mouthing hands and objects. Pollutants adhering to hands, toys, food and other objects are easily transferred to the mouth and ingested [29]. Contamination can occur to food during processing, distribution, storage, preparation and consumption.

\subsubsection{Dermal}

exposure on the other hand can occur during contact with contaminated media like water, soil, sediment, liquid, vapours/fumes while performing activity [30]. Dermal exposure can emanate from volatile substance deposition on skin directly 
or indirectly through surface/cloth transfer to skin and absorption into the body system [31].

\section{Methodology}

The vector shapefiles used are GPS position of the 443 oil spill sites collected by the Department of Petroleum Resources (DPR) Lagos, Nigeria. Land use map dataset was obtained from the Department of Geography in the University of Lagos. 354 gazetted rural communities were also sourced from the University of Lagos to augment towns on the DPR's legacy map. The communities are represented by points due to lack of polygon shapefiles. 2002 projected population data was collected from the National Population Commission (NPC) Abuja, because the 2006 village population data has not been published yet. A SPOT $^{\circledR}$ satellite imaging was used to digitise the pipeline network via onscreen digitisation.

\subsection{Data analysis and result}

The datasets were first projected to UTM_Zone32N in meters from decimal degrees; secondly the community shapefile was updated with the population data, and then further converted to geodatabase to facilitate automatic update of parameters like shape (area) and length. Proximity analysis performed to determine the distance of communities to pipeline gave a mean distance of $2.35 \mathrm{~km}(\mathrm{SD}=1.99 \mathrm{~km})$, indicating the closeness of the communities to pipelines. Further proximity assessment performed for distance of communities to rivers and creeks gave a mean distance of $0.57 \mathrm{~km}(\mathrm{SD}=0.58 \mathrm{~km})$. For the communities proximity to oil spill sites, gave a mean distance of $4.47 \mathrm{~km}(\mathrm{SD}=3.72 \mathrm{~km})$. The population data gave a mean of $3,858.9(\mathrm{SD}=8,104.4)$ persons per community. Since 1985 to 2008 a total of 129,578 barrels of crude oil have been spilt, giving a mean value of $292.5(\mathrm{SD}=511.8)$. About $314.3 \mathrm{~km}$ pipeline representing $7.28 \%$ of the $4,315 \mathrm{~km}$ multi-product pipelines in the Niger Delta was digitised within the study area.

\section{Discussion: risk assessment}

The activities identified are performed out-doors with environmental media that may serve as vectors for contaminants. Because the people walk a great distance across the area, there is the chance of having contact with contaminants along their path, e.g. polluted river or ruptured pipeline. This is justifiable since the mean distance of communities to pipelines, rivers and oil spill sites is $2.35 \mathrm{~km}$, $0.5 \mathrm{~km}$ and $4.47 \mathrm{~km}$ respectively. Therefore those involved in any of these activities are at risk because of their proximity to pipelines and river which might convey contaminants. In Figure 3, pipeline intersection with river was buffered at an interval of $0.5 \mathrm{~km}, 1 \mathrm{~km}$ and $1.5 \mathrm{~km}$ to demonstrate the extent to which a spill may spread along the river overtime, though this will depend on quantity, 


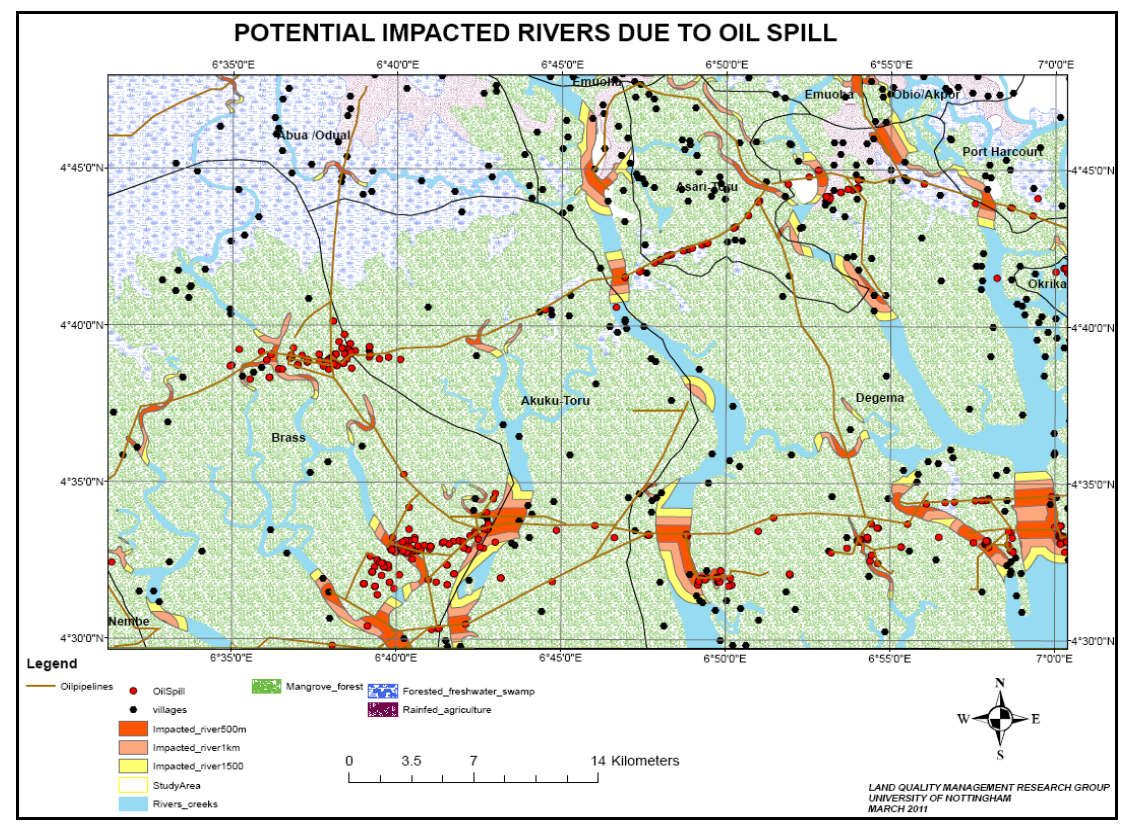

Figure 2: $\quad$ Potential impacted site at pipeline and river intersection.

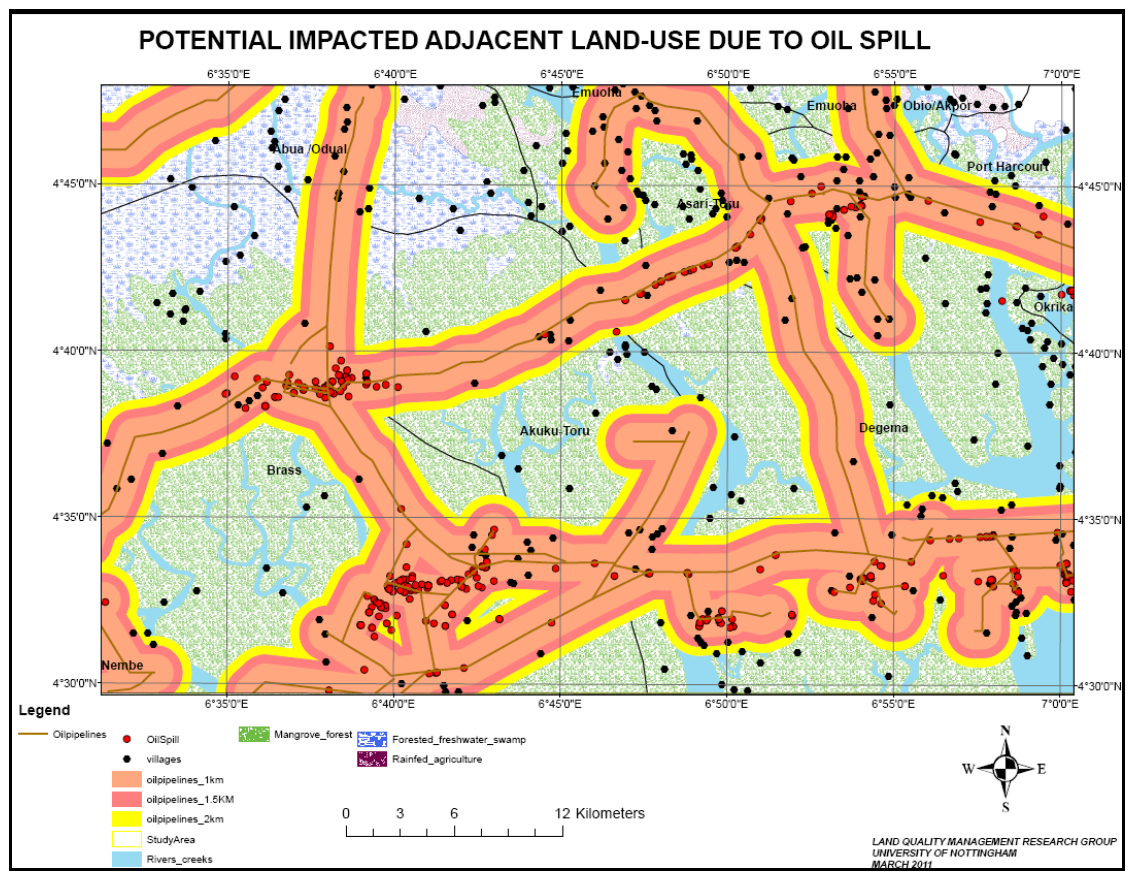

Figure 3: $\quad$ Potential impacted land use by oil spill. 
pressure, duration of discharge and most importantly behaviour of the river at the time of discharge [32]. The extent of spread can be detrimental to water basedactivities in the area.

Figure 4, on the other hand is a buffer of pipeline network with relation to land use and community location. The buffer distance of $1 \mathrm{~km}, 1.5 \mathrm{~km}$ and $2 \mathrm{~km}$ was used as criterion to determine the difference in community and population sizes with increases in distance to the pipeline. The following were identified within the buffer zones i.e. $1 \mathrm{~km}=114$ communities, mean population 3877.1 $(\mathrm{SD}=7133) ; 1.5 \mathrm{~km}=159$ communities, mean population $4420.1(\mathrm{SD}=11007.1)$ and $2 \mathrm{~km}=188$ communities, mean population of $4266.2(\mathrm{SD}=10212.5)$. It is assumed that since the primary cause of oil spill is due to pipeline rupture caused by vandalism/sabotage, discharge can occur from any part of the network. Thus any activities within these areas might be susceptible to exposure.

\subsection{Exposure assessment}

This employ the use of models to estimate the degree of exposure to specific environmental contaminants by assessing exposure duration, exposure frequency, magnitude of exposure, concentration of contaminant and pattern of activity undertaken by the receptor. It also takes into account bodyweight and gender of the receptor at risk through established exposure pathways [33]. Thus by relating a receptor to a possible exposure pattern, an average daily exposure can be estimated as in Table 1, where exposure duration (ED) and averaging time (AT) have been assumed for each activity according to age and gender. The ED is determined in year (i.e. hours/day/year) while AT is the assumed exposure duration given in days. A 50 years life expectancy at birth of has been assumed for the benefit of this work, although the CIA [34] and UNHDR [35] have published 47.56 and 48.4 years respectively. These parameters can be used in the Average Daily Exposure equation while others may be adopted from recommended values in USEPA [29] and Environmental Agency [27].

Although different countries and organisations have developed different models for estimating exposure through ingestion, inhalation and dermal contact, the Average Daily Exposure (ADE) model developed by [28] in Contaminated Land Exposure Assessment (CLEA) for assessing exposure through contaminated soil (see equation 1) has been found to be appropriate for the Niger delta in our research for the following reasons: a) it combine the three exposure routes, b) the variables can easily be modified using parameters developed for other countries, c) it can take care of lack of indigenous data from Nigeria. The ADE can be used for exposure to chemicals with non-carcinogenic effects. However, for compounds with carcinogenic or chronic effects, the lifetime average daily dose (LADD) can be evoked "The LADD is the dose rate averaged over a lifetime" [36, 37].

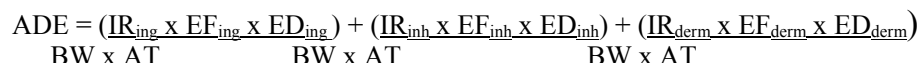

where: $\mathrm{ADE}=$ the average daily human exposure to chemical from soil $\left(\mathrm{mg} \mathrm{kg}^{-1}\right.$ bw day $\left.^{-1}\right), I R=$ the chemical intake/uptake rate $\left(\mathrm{mg} /\right.$ day $\left.^{-1}\right), E F=$ the exposure 
frequency (days year ${ }^{-1}$ ), $\mathrm{ED}=$ the exposure duration (year), $\mathrm{BW}=$ the human body weight $(\mathrm{kg}), \mathrm{AT}=$ the averaging time (days), Note: ing, inh and derm stands for ingestion, inhalation and dermal contact.

Table 1: Exposure duration and averaging time for specific activity according to age.

\begin{tabular}{|c|c|c|c|c|c|c|}
\hline $\begin{array}{c}\text { Receptor } \\
\text { Age Group }\end{array}$ & Fishing & $\begin{array}{c}\text { Animal } \\
\text { herding }\end{array}$ & $\begin{array}{c}\text { Fetching } \\
\text { Water }\end{array}$ & $\begin{array}{l}\text { Fuelwood } \\
\text { Gathering }\end{array}$ & Hunting & Farming \\
\hline $\begin{array}{l}\text { Adult male } \\
20-50 \text { years }\end{array}$ & $\begin{array}{c}\mathrm{ED}= \\
6 \mathrm{hrs} / \text { dayx365 } \\
\mathrm{AT}=365 \times 50 \\
(18,250 \text { days })\end{array}$ & $\begin{array}{c}\mathrm{ED}= \\
8 \mathrm{hrs} / \text { dayx365 } \\
\mathrm{AT}=365 \times 50 \\
(18,250 \text { day })\end{array}$ & N/A & N/A & $\begin{array}{c}\mathrm{ED}= \\
6 \mathrm{hrs} / \text { dayx365 } \\
\mathrm{AT}=365 \times 50 \\
(18,250 \text { days })\end{array}$ & $\begin{array}{c}\mathrm{ED}= \\
8 \mathrm{hrs} / \text { dayx } 365 \\
\mathrm{AT}=365 \times 50 \\
(18,250 \text { day })\end{array}$ \\
\hline $\begin{array}{c}\text { Adult } \\
\text { female } \\
18-50 \text { years }\end{array}$ & N/A & N/A & $\begin{array}{c}\mathrm{ED}= \\
6 \mathrm{hrs} / \text { dayx365 } \\
\mathrm{AT}=365 \times 50 \\
(18,250 \text { days })\end{array}$ & $\begin{array}{c}\mathrm{ED}= \\
6 \mathrm{hrs} / \text { dayx365 } \\
\mathrm{AT}=365 \times 50 \\
(18,250 \text { days })\end{array}$ & N/A & $\begin{array}{c}\mathrm{ED}= \\
6 \mathrm{hrs} / \text { dayx } 365 \\
\mathrm{AT}=365 \times 50 \\
(18,250 \text { days })\end{array}$ \\
\hline $\begin{array}{l}\text { Boy child } \\
7-19 \text { years }\end{array}$ & $\begin{array}{c}\mathrm{ED}= \\
6 \mathrm{hrs} / \text { dayx365 } \\
\mathrm{AT}=365 \times 19 \\
(6,935 \text { days })\end{array}$ & $\begin{array}{c}\mathrm{ED}= \\
8 \mathrm{hrs} / \text { dayx365 } \\
\mathrm{AT}=365 \times 50 \\
(18,250 \text { day })\end{array}$ & N/A & N/A & $\begin{array}{c}\mathrm{ED}= \\
\text { 4hrs/dayx365 } \\
\mathrm{AT}=365 \times 19 \\
(6,935 \text { days })\end{array}$ & $\begin{array}{c}\mathrm{ED}= \\
4 \mathrm{hrs} / \text { dayx } 365 \\
\mathrm{AT}=365 \times 19 \\
(6,935 \text { days })\end{array}$ \\
\hline $\begin{array}{l}\text { Girl child } \\
7-17 \text { years }\end{array}$ & N/A & N/A & $\begin{array}{c}\mathrm{ED}= \\
6 \mathrm{hrs} / \text { dayx365 } \\
\mathrm{AT}=365 \times 17 \\
(6,205 \text { days })\end{array}$ & $\begin{array}{c}\mathrm{ED}= \\
6 \mathrm{hrs} / \text { dayx365 } \\
\mathrm{AT}=365 \times 17 \\
(6,205 \text { days })\end{array}$ & N/A & $\begin{array}{c}\mathrm{ED}= \\
\text { 4hrs/dayx365 } \\
\mathrm{AT}=365 \times 17 \\
(6,205 \text { days })\end{array}$ \\
\hline $\begin{array}{l}\text { Infant child } \\
\text { (boy/girl) } \\
\leq 6 \text { years }\end{array}$ & N/A & N/A & $\begin{array}{c}\mathrm{ED}= \\
6 \mathrm{hrs} / \text { dayx365 } \\
\mathrm{AT}=365 \times 6 \\
(2,190 \text { days })\end{array}$ & $\begin{array}{c}\mathrm{ED}= \\
6 \mathrm{hrs} / \text { dayx365 } \\
\mathrm{AT}=365 \times 6 \\
(2,190 \text { days })\end{array}$ & N/A & $\begin{array}{c}\mathrm{ED}= \\
6 \mathrm{hrs} / \text { dayx365 } \\
\mathrm{AT}=365 \times 6 \\
(2,190 \text { days })\end{array}$ \\
\hline
\end{tabular}

Note: it is assumed that the infant child spend time with their mother while they perform their activity.

ED $=$ Exposure duration, $\mathbf{A T}=$ Averaging time, $\mathrm{N} / \mathrm{A}=$ Not Applicable.

\subsection{Relative risk ranking}

According to the activity-based relative risk ranking in Table 2, the receptor most susceptible are children, because of their bodyweight and the fact that they are more easily tempted to interact with contaminated media than adults. The relative risk ranking used weighting system to qualify involvement in each activity according to age and sex. After ranking the normalised weight, the result shows infants to be higher because they are always accompany their mothers or grandparents; who might be involved in all or most of the activities, followed by the male child; who may perform similar tasks alongside their female siblings, then the female child; who may not necessarily be engaged in young male tasks like hunting, animal Herding and fishing. Child exposure through hand-tomouth, soil ingestion and general attraction to contaminated media on play ground, clearly distinguished them as the receptors of greatest concern.

\section{Conclusion}

The possible continuing opportunities for human contact with contaminated media in everyday rural activities should be a concern to stakeholders in the oil industry. For example, opportunities that enable hand-to-mouth scenarios in children and adults or tracking of contaminants outdoors may cause long lasting 
Table 2: $\quad$ Relative risk ranking of receptors with respect to activities.

\begin{tabular}{|c|c|c|c|c|c|c|c|c|}
\hline $\begin{array}{l}\text { Potential } \\
\text { receptor }\end{array}$ & Farming & Hunting & $\begin{array}{c}\text { Water } \\
\text { collection }\end{array}$ & $\begin{array}{l}\text { Fuelwood } \\
\text { gathering }\end{array}$ & Fishing & $\begin{array}{l}\text { Animal } \\
\text { rearing }\end{array}$ & Total & Rank \\
\hline $\begin{array}{l}\text { Adult male } \\
\text { (20-50yrs) }\end{array}$ & $1(0.067)$ & $4(0.267)$ & $1(0.067)$ & $1(0.067)$ & $1(0.067)$ & $4(0.267)$ & $12(0.133)$ & 5 \\
\hline $\begin{array}{l}\text { Male Child } \\
(7-19 y r s)\end{array}$ & $2(0.133)$ & $5(0.333)$ & $2(0.133)$ & $2(0.133)$ & $5(0.333)$ & $5(0.333)$ & $21(0.233)$ & 2 \\
\hline $\begin{array}{c}\text { Adult Female } \\
(18-50 \mathrm{yrs})\end{array}$ & $4(0.267)$ & $3(0.200)$ & $3(0.200)$ & $3(0.200)$ & $2(0.133)$ & $2(0.133)$ & $17(0.189)$ & 4 \\
\hline $\begin{array}{c}\text { Female Child } \\
(7-17 \mathrm{yrs})\end{array}$ & $3(0.200)$ & $2(0.133)$ & $4(0.267)$ & $4(0.267)$ & $3(0.200)$ & $3(0.200)$ & $19(0.211)$ & 3 \\
\hline $\begin{array}{l}\text { Infants } \\
\leq 6 \text { yrs }\end{array}$ & $5(0.333)$ & $1(0.067)$ & $5(0.333)$ & $5(0.333)$ & $4(0.267)$ & $1(0.067)$ & $21(0.233)$ & 1 \\
\hline Total & $15(1.000)$ & $15(1.000)$ & $15(1.000)$ & $15(1.000)$ & $15(1.000)$ & $15(1.000)$ & $90(1.000)$ & \\
\hline
\end{tabular}

exposure and pose serious health risks [31]. According to [33] there are "no reliable quantitative data to support Human Health Risk Assessment for activities associated with receptors living in rural areas, or for lifestyles and occupations such as farming, where there is the potential for high exposures". Lifestyles in rural areas predispose people to different exposure pathways because they conduct their activities under environmental conditions that guarantee the likelihood of intake/uptake of contaminated substances. As a result, exposure estimates for rural population associated with traditional land use practices are limited to qualitative assessments which are based on data extrapolated from other studies like [33].

While discussing the basic elements considered in assessing exposure to environmental contaminants, it is obvious that exposure during activities may occur simultaneously through several routes while in some cases only one may be available. This is because contaminants are not equally distributed spatially due to dispersion, diffusion and other mechanism responsible for loss of concentration, therefore the closer a receptor is to the source the higher the chances of multiple exposure routes.

Finally, in view of lack of data from the area, information from the Environmental Protection Agency (USA) and the Environment Agency (UK) has been adopted. Such exposure models can serve as a trigger for further research and development of a human health risk criteria for petroleum hydrocarbon contaminants in the Niger Delta. This study has provided a basis for further investigation into petroleum hydrocarbon contamination and its potential exposure pathways in the area.

\section{References}

[1] Royal Dutch Shell PLC Sustainability Report 2009, www.shell.com

[2] ONUOHA, F., Poverty, pipeline vandalisation /explosion and human security: Integrating disaster management into poverty reduction in Nigeria. African Security Review 16.2, www.iss.co.za 
[3] Akpan, W.N., Between that "Sectional" and the "National" oil, Grassroots discontent and civic discourse in Nigeria. PhD thesis submitted to Rhodes University, 2005, http://eprints.ru.ac.za/249/1/Akpan-PhD.pdf

[4] This Day, Shell Faces Dutch Parliament over Nigeria. http://www.thisdayonline.com

[5] Amnesty International., Nigeria: Petroleum, Pollution and Poverty in the Niger Delta. Amnesty International Publications 2009, www.amnesty.org

[6] Nigerian National Petroleum Corporation, Annual Statistical Bulletin, www.nnpcgroup.com

[7] National Population Commission of Nigeria, Facts and Figures, www.population.gov.ng

[8] Omo-Irabor, O.O., Olobaniyi, S.B., Oduyemi, K. and Akunna, J., Surface and groundwater quality assessment using multivariate analytical methods: A case study of the Western Niger Delta, Nigeria. Physics and Chemistry of the Earth. 33, pp.666-673, 2008.

[9] Togunde, D. and Richardson, S., Household size and composition as correlates of child labour in urban Nigeria. African Development, Vol. XXXI(1), pp.50-65, 2006.

[10] Kassali, R., Ayanwale, A.B. and Williams, S.B., Farm location and determinants of agricultural productivity in the Oke-Ogun area of Oyo state, Nigeria. Journal of Sustainable Development in Africa. 11(2), pp.1$18,2009$.

[11] Ismaila, U., Gana, A.S., Tswanya, N.M. and Dogara, D., Cereals production in Nigeria: problems, constraints and opportunities for betterment. African Journal of Agricultural Research. 5(12), pp.1341-1350, 2010.

[12] Baker, L.R. and Olubode, O.S., Correlates with the distribution and abundance of endangered sclater's monkeys (cercopithecus sclateri) in southern Nigeria. African Journal of Ecology. 44, pp.365-373, 2007.

[13] Jamabo, N.A., and Ibim, A.T., Utilization and protection of the brackish water ecosystem of the Niger Delta for sustainable fisheries development. World Journal of Fish and Marine Sciences. 2(2), pp.138-141, 2010.

[14] Tawari, C.C. and Davies, O.A., Impact of multinational corporations in fisheries development and management in Niger Delta Nigeria. Agriculture and Biology Journal of North America, 1(2), pp.146-151, 2010.

[15] United Nations Development Programme., Niger Delta human development report. UNDP, UN House, Abuja, Nigeria. 2006.

[16] Achudume, A.C., Environmental health, development and economic empowerment of rural women in Nigeria. Environment Development and Sustainability. 11, pp.459-469, 2009.

[17] Kuehi, H.S., Nzeingui, C., Yeno, S.L.D., Huijbregts, B., Boesch, C. and Walsh, P.D., Discriminating between village and commercial hunting of apes. Biological Conservation, 142, pp.1500-1506, 2009.

[18] Greengrass, E., Chimpanzees are close to extinction in southwest Nigeria. Primate Conservation, 24, pp.77-83, 2009. 
[19] Adebayo, A.G., Oyun, M.B. and Kadeba, O., Access of rural women to forest resources and its impact on rural household welfare in North Central Nigeria. Forest Policy and economics. 12, pp.439-450, 2010.

[20] Adeoti, O., Idowu, D.O.O. and Falegan, T., Could fuelwood use contribute to household poverty in Nigeria. Biomass and Bioenergy. 21, pp. 205-210, 2010.

[21] Ikurekong, E. E., Esin, J. O. and Mba, A. C., Rural fuelwood exploitation in Mbo local government area- A Nigerian coastal settlement. Ethiopian Journal of Environmental Studies and Management. 2(3), pp.44-55, 2009.

[22] WaterAid. Women's issues. 2009, www.wateraid.org

[23] Nkwocha, E.E., Water supply deficiency and implications for rural development in the Niger-Delta Region of Nigeria. Soc Inic Res. 90, pp.409-418, 2008.

[24] DEFRA Environmental Protection Act 1990: Part 2A. Contaminated Land Circular 01/2006. Defra: London, 2006

[25] Elert, M., Bonnard, R., Jones, C., Schoof, R.A., and Swartjes, F.A., Human Exposure Pathways. Swartjes, F.J. (ed) Dealing with Contaminated sites. 3, pp.455-515, 2011.

[26] Swartjes, F.A., and Cornelis, C., Human Health Risk Assessment. Swartjes, F.J. (ed) Dealing with Contaminated sites. 3, pp.209-259, 2011.

[27] Environment Agency Science Report: SC050021/SR3. Updated technical background to the CLEA model. Environment Agency UK, 2009.

[28] US-EPA. Child-specific exposure factors handbook (final report). United States Environmental Protection Agency. EPA/600/R-06/096F. National Center for Environmental Assessment office of Research and Development, Washington, DC 20460. 2008, www.epa.gov/ncea.

[29] US-EPA. Exposure Factor Handbook., United States Environmental Protection Agency, Washington, www.epa.gov/ncea

[30] Kimbrough, R.D., Krouskas, C.A., Carson, M.L., Long, T.F., Bevan, C., and Tardiff, R.G., Human uptake of persistant chemicals from contaminated soil: PCDD/Fs and PCBs. Regulatory Toxicology and Phermacology. 57, pp.43-54, 2010.

[31] Fingas, M., The Basics of Oil Spill Cleanup. Edited by Jennifer Charles; Second Edition. Lewis Publishers London, 2000.

[32] International Programme on Chemical Safety (IPCS). Human Exposure Assessment. Environmental Health Criteria; 214. Geneva, World Health Organisation. 2000.

[33] Doyle, J.R., Blais, J.M. and White, P.A., Mass Balance soil ingestion estimation methods and their application to inhabitants of rural and wilderness areas: a critical review. Science of the Total Environment. 408, pp.2181-2188, 2010.

[34] CIA World Fact book , www.cia.gov/library/publications/the-worldfactbook/geos/ni.html

[35] UNHDR, http://hdrstats.undp.org/en/countries/profiles/NGA.html 